\author{
Aleksandr SZYRINIANC \\ Moskiewski Uniwersytet Państwowy im. M. Łomonosowa \\ jants@mail.ru
}

\title{
Anna MYRIKOWA
}

Moskiewski Uniwersytet Państwowy im. M. Łomonosowa

an_my@mail.ru

\section{„WEWNĘTRZNA” RUSOFOBIA I „KWESTIA POLSKA” W ROSJI W XIX W.}

ABSTRACT The „internal” Russophobia and „the Polish issue” in $19^{\text {th }}$ century Russia The article is devoted to the phenomenon of Russophobia in Russia in XIX century. Outstanding Russian thinker and poet F. I. Tyutchev, who introduced the word Russophobia, characterized it as a multifaceted phenomenon. He drew attention to the fact that, apart from the western Russophobia there was an „internal” Russian Russophobia. An important part of it became the so-called „Polish elements” as the result of the unresolved of the most accurate issues of the internal policy of Russia - the Polish question. The article presents the views of Russian journalism of those times on this topic. The works of F. H. Duhinski and J. Piłsudski are presented as examples of Polish Russophobia.

Keywords: Russia, the XIX century, Russophobia, „Internal” Russophobia, „Polish question”, F.I. Tyutchev, F.H. Duchiński, J. Piłsudski

Słowa kluczowe: Rosja, wiek XIX, rusofobia, „wewnętrzna” rusofobia, „kwestia polska”, F. Tiutczew, F. Duchiński, J. Pisłudski 
S wego czasu wielki myśliciel rosyjski Iwan Iljin w krótkim artykule Polityka światowa S wtadców rosyjskich (Мировая политика русских государей) - z 1949 r., wymieniając charakterystyczne cechy stosunku Zachodu do Rosji w XIX w., napisał, że odkrył w Europie gniazdo ztych emocji: strachu, pychy, wrogości, zawiści i absurdalnych oszczerstw. Wyczerpujące, dokładne i wyraziste sformułowanie Iljina, wyjaśniające istotę takiego stosunku, sprowadza się do następującego:

Europejczycy „potrzebuja” gtupiej Rosji: barbarzyńskiej, aby „cywilizowaci” ja na swój sposób; groźnej ze względu na swoje rozmiary, aby można ja byto podzielić; agresywnej, aby organizować koalicje przeciwko niej; reakcyjnej, aby usprawiedliwić w niej rewolucje $i$ żąać dla niej ustroju republikańskiego; upadającej religijnie, aby wedrzé́ się do niej z propaganda reformacji lub katolicyzmu; gospodarczo niesamodzielnej, aby rościć sobie prawo do jej „niewykorzystanych” przestrzeni i jej surowców lub przynajmniej korzystnych umów handlowych i koncesji. Ale jeśli tę „zgnita” Rosje można wykorzystać strategicznie, to Europejczycy sa gotowi zawrzeć z nia sojusze i wymagać od niej jej wysitku wojennego „do ostatniej kropli jej krwi'”.

Iljin „zmodernizował” tutaj znaczenie pojęcia, które, jak tradycyjnie utarło się sądzić, po raz pierwszy wprowadził do obiegu publicznego Fiodor Tiutczew ${ }^{2}$, wskazując, że podstawą rusofobii jest nienawiść, płomienna, ślepa i gwałtowna wrogość wobec Rosji ${ }^{3}$.

Pojawienie się obrazu Rosji - „potwora”, „ludożercy XIX wieku”“ w świadomości społecznej Europejczyków, z punktu widzenia Tiutczewa było uwarunkowane głębokimi różnicami cywilizacyjnymi między Europą Zachodnią i Wschodnią (czyli Rosją prawowitą siostrą chrześcijańskiego Zachodu, niefeudalną i niehierarchiczną i dlatego właśnie jeszcze bardziej autentycznie chrześcijańską, całym światem, jednolitym dzięki swoim źródłom, solidarnym w swoich częściach, żyjącym swoim własnym organicznym, odrębnym życiem ${ }^{5}$ ), brakiem zrozumienia systemu społecznego, cywilizacji, która zastąpi zachodnią: Ludzie Zachodu wyrażający opinię o Rosji przypominaja Chińczyków wyrażajacych opinię o Europie ${ }^{6}$. Do „niezrozumienia” dochodzi jeszcze „moralna nieod-

1 И. Ильин, Мировая политика русских государей, [w:] tenże, Наши задачи. Статьи 1948-1954 22., t. 1, Париж 1956, s. 93.

2 W. Kożynow w swoich pracach (O rosyjskiej świadomości narodowej [O русском национальном сознании], Prorok we wtasnym kraju (Fiodor Tiutczew - Rosja wiek XIX) [Пророк в своем отечестве (Федор Ттотчев - Россия век XIX)], Los Rosji: wczoraj, dzis, jutro [Cудьба Poсcuи: вчера, сегодня, завmpa]), wskazując, że to właśnie Tiutczew wprowadził do leksykonu społeczno-politycznego termin „rusofobia”, jako dowód przytaczał słowa z listu poety do córki Anny z 26 IX 1867 r.: Można bytoby przeanalizowaćć wspótczesne zjawisko, przybierające coraz bardziej patologiczny charakter. To „rusofobia” niektórych Rosjan - skądinąd bardzo szanowanych. Tiutczew mówi tutaj o rosyjskich liberałach-okcydentalistach.

3 Ф. Тютчев, Россия и Запад. Книга пророчеств. Статьи, стихи, Москва 1999, s. 191.

Tamże, s. 176.

Tamże, s. 182.

Tamże, s. 100. 
powiedzialność" ${ }^{\prime}$. Przy tym, jak subtelnie zauważył Tiutczew, opinię publiczną nastawiają przeciw Rosji nie realne niedoskonatości naszego systemu spotecznego, wady naszej administracji, potożenie najniższych warstw naszego narodu ${ }^{8}$, lecz same źródła cywilizacji (historia bez feudalizmu, walk religijnych, papieskiej hierarchii, wojen imperialnych, inkwizycji, rycerstwa; jedność i istnienie „źródłowego pierwiastka” [„основное начамо"], który nie zapewnia wystarczającej przestrzeni dla wolności osobistej, nie daje możliwości rozdzielenia i rozdrobnienia ${ }^{9}$ ). W związku z tym myśliciel podkreśla również instynktowną naturę rusofobii, pojawiającej się u ludzi Zachodu wobec materialnej siły Rosji. To instynktowne odczucie - cośpomiędzy szacunkiem i strachem - to odczucie awe (pełnej uwielbienia trwogi [uwaga F. Tiutczewa ${ }^{10}$ ]), które żywi się tylko w stosunku do Wtadzy ${ }^{11}$.

Wraz z „zewnętrzną", zachodnią rusofobią nastroje rusofobiczne, rusofobiczny sposób myślenia i działania istniały w samym Imperium Rosyjskim. Zwrócił na to uwagę Tiutczew, który interpretował rusofobię jako zjawisko wieloaspektowe. Obok „zewnętrznej” rusofobii społeczeństwa zachodnioeuropejskiego ze zjednoczonymi w uczuciu nienawiści do Rosji z „propagandami” - katolicką, rewolucyjną itp., którym wtóruje „drwiące echo” - zachodnia kolonia wykształconych Rosjan ${ }^{12}$, myśliciel wskazuje na podobne zjawiska wewnątrz Imperium Rosyjskiego, przy czym - nie tylko w kręgach liberałów, nihilistów-rewolucjonistów, „opozycji polskiej”, junkierstwa z regionu nadbałtyckiego, ale także w rządzie, gdzie niszczące działania prowadziła, jak ją określił, „antyrosyjska klika”'13 - wszystkie elementy albo nierosyjskiego pochodzenia, albo

\section{Por. tamże, s. 191.}

8 Tamże, s. 193.

9 Por. tamże, s. 192.

10 Tiutczew wprowadza do swojego tekstu angielskie słowo 'awe', które znaczy: the feeling of respect and amazement that you have when you are faced with something wondeful, frightening or completely unknown. Zob. C. Cobuild, English Language Dictionary, London-Glasgow 1988, s. 88 [przypis Redakcji].

11 Tamże, s. 100-101.

12 Por. tamże, s. 100, 148. Rosyjscy liberałowie-okcydentaliści, mieszkający w Europie i w Rosji, to ludzie, którzy są zupełnie pozbawieni „uczuć narodowych” i których rusofobia, jak sądzi Tiutczew, jest instynktowna, bezzasadna, nie ma żadnej logiki, a w ogóle jest irracjonalna: Wcześniej mówili nam i rzeczywiście tak sądzili, że nienawidza w Rosji bezprawia, braku swobody druku itp. itd. i dlatego tak czule kochaja Europe, bo ona bezsprzecznie ma wszystko to, czego nie ma w Rosji... A co widzimy teraz? $W$ miarę tego, jak Rosja, zdobywając coraz więcej wolności, coraz bardziej się uniezależnia, niechęć tych panów do niej tylko się nasila. W istocie, stare porządki nigdy nie wywotywaty w nich takiej gorliwej nienawiści, z jakq nienawidzq wspótczesne kierunki życia spotecznego w Rosji. I przeciwnie widzimy, że $\dot{z} a d n e$ naduzycia w sferze sądownictwa, moralności, a nawet cywilizacji, na które przyzwala się w Europie, wżaden sposób nie zmniejszyty ich stabości do niej.Zob. Ф. Тютчев, Письма кмосковским публиистам. И. С.и А. Ф. Аксаковым. 1861-1872.27. А. Ф. Аксаковой, Петербург. Среда, 20 сент[ября] [1867], [w:] Федор Иванович Ттотчев, red. С. Макашин, К. Пигарев, Т. Аинесман, ks. 1, Москва 1988, s. 306, Аитературное наследство, t. 97. Mówiąc o „antyrosyjskiej klice”, Tiutczew miał przede wszystkim na myśli konkretne osoby w rządzie i kierownictwie imperium, które przeciwistawiał panującym samodzierżcom, będącym poza wszelką krytyką za życia.

13 Klika będąca teraz u wtadzy - pisał - prowadzi dziatalność wybitnie antydynastyczną. Jeśli się utrzyma, 
nastawione antyrosyjsko. Ta koalicja wszystkich antyrosyjskich tendencji $w$ Rosji jest faktem oczywistym, namacalnym [...], w sktad tej koalicji, mimo różnorodności weszta i polska szlachta, i baronowie w prowincjach battyckich i petersburscy nibiliści, etatowi i pozaetatowi. Łaczy ich jedno - pierwiastek negatywny, tj. wrodzona lub zaszczepiona wrogość wobec wszystkiego, co rosyjskie $[\ldots]^{14}$.

$\mathrm{Z}$ tych symptomów, które opisał i ostro skrytykował Tiutczew, wyłania się obraz „wewnętrznej” rusofobii.

Jedną ze składowych „wewnętrznej rusofobii” w Rosji XIX w. byli, zdaniem Tiutczewa, „,nihiliści” i „element polski”, których on, w ślad za Michaiłem Katkowem, łączy, dopatrując się w nihilistycznych dążeniach rewolucyjnych wzmacniającego je wsparcia Polaków, podejrzewając nawet „polską intrygę” w wystrzale Karakozowa ${ }^{15}$. „Nihiliści”, jak sądził Tiutczew, na początku lat 60. XIX w. byli niczym „zagubione owce”, bydło wierzgające od czasu do czasu:

Wtaśnie przeczytatem w stowniku Dala stowo „wierzganie” [брык], oto, jak go definiuje: bieganie bydta, gdy w upalny sprzyjajacy gzom czas, z podniesionym ogonem miota się tam i z powrotem, i ryczy [...]. W tym kontekście możemy powiedzieć z literalna doktadnościa: to wierzganie naszego mtodego pokolenia - naszej „Jeune Russie”.

Rolę gza w odniesieniu do nihilistów spełnia policja i władza w ogóle, która $z$ po-

to doprowadzi wtadze panująca do tego, że nie tylko straci ona popularność, ale nabędzie antyrosyjskiego charakteru. A w innym miejscu: Te szumowiny spoteczeństwa rosyjskiego, to antyrosyjskie nasienie, nie może nie widzieć $w$ nim swego najgorszego wroga... Zob. Ф. Тютчев, Письма к московским публичистам... 58. А. Ф. Аксаковой. [Петербург]. 2 января [1869], [w:] Федор Иванович..., s. 352. W liście do Anny Aksakowej Tiutczew wspomina jej męża - Iwana Siergiejewicza Aksakowa, który, wg autora listu, jest postrzegany przez liberałów-okcydentalistów jako ich najgorszy wróg [uwaga Redakcji]). To klika, która zagarnęta wtadzę i wptywy i straszy Rosję, a nie rządzi nią. Ф. Тютчев, Письма к московским публииистам... 58. И. С. Аксакову. С.-Петерб[ург]. Среда, 19 февраля [1869], [w:] Федор Иванович..., s. 355. Tiutczew nazywał ministrów tajdakami, a działania rządu charakteryzował jako jawny bezwstyd, jawna gtupote itp. Por. Ф. Тютчев, Письма к московским публиистам..., А. Ф. Аксаковой. Петербург. 7 декаб[ря] 1870, [w:] Федор Иванович.., s. 365 $\mathrm{i}$ in. Tiutczew był przy tym zagorzałym monarchistą, stronnikiem i ideologiem, teoretykiem idei imperialnej, nie rozważał „klasowej” podstawy władzy, uważając za taką podstawę i kryterium jej boskie pochodzenie i moralność jej przedstawicieli. Por. Ф. Тютчев, Письмо к А. А. Блудовой от 28 сент. 1857 г., [w:] tenże, Сочинения в 2 mомах, t. 2: Письма, Москва 1980, s. 184 in. Pisząc o rusofobicznej „klice” w rządzie, wychodził od tego, że działania takich ludzi przede wszystkim niszczyły prasę rosyjską, utrudniały kształtowanie samoświadomości społeczeństwa rosyjskiego, co $\mathrm{w}$ istocie czyniło tę klikę rusofobiczną.

14 Тепże, Письма к московским публииистам. А. И. Георгиевскому 1864-1866. 5. Нициа. 2/14 января 1865, [w:] Федор Иванович..., s. 387.

15 Dymitr Karakozow (1840-1866) - członek terrorytycznego antycarskiego kółka Mikołaja Iszutina. 4 kwietnia 1866 r. dokonał nieudanego zamachu na cara Aleksandra II, za co został skazany na śmierć i powieszony. Michał Heller podaje, że kiedy doprowadzono Karakozowa przed cara, między imperatorem i zamachowcem wywiązała się następująca rozmowa, rozpoczęta pytaniem władcy: Jesteś na pewno Polakiem?. Odpowiedź Karakozowa brzmiała: Nie, jestem czystej krwi Rosjaninem. Zob. M. Heller, Historia Imperium Rosyjskiego, przeł. E. Melech, T. Kaczmarek, Warszawa 2000, s. 603 [przypis Redakcji].

16 Ф. Тютчев, Письма к московским публииистам... 27. И. С. Аксакову. [Петербург.] 23 октягря 1861, [w:] Федор Иванович..., s. 263. 
wodu braku zasad i przekonań moralnych przechodzi do środków przemocy fizycznej przez co przeksztatca się w najokropniejszego wspólnika Negacji i obalajacej wtadze Rewolucji $i^{17}$. Nihilistów, którymi coraz bardziej zapetnia się ziemia ruska, jak jakimś gazem, wytworzonym w bożym świecie dzięki życiodajnemu cieptu pierwiastka policyjne$g o^{18}$, Tiutczew uważał za wyrodków ludzkiej myśli, zrodzonych nie tylko przez wpływy zachodnie, ale także przez bezprawie i tłumienie myśli w samej Rosji. To że wyznawane przez nihilistów rewolucyjne teorie socjalistyczne są związane z anarchią, ateizmem i amoralnością, a prowokowane przez zakazy, represje, niezdolność władzy do przeciwstawienia im adekwatnych środków ideologicznych, po raz kolejny przekonująco pokazal pierwszy proces polityczny w Rosji - sąd nad "nieczajewcami” w 1871 r., na którego posiedzeniach bywał Tiutczew. Myśliciel był głęboko przekonany, że represywne oddziaływanie siłą na wszelkie przejawy zła nie zawsze jest jedynym przydatnym i możliwym narzędziem: czasem narzędzie to staje się nieprzydatne - nieprzydatne ze względu na fakt, że daje fatszywe poczucie bezpieczeństwa, które pozwala zapominać o konieczności posiadania znacznie bardziej skutecznej broni ${ }^{19}$. „Szkodliwym” teoriom, złudzeniom socjalistycznym i „porywom serca” rewolucjonistów należy przeciwstawić zasady prawdziwego konserwatyzmu, samodzierżawia i duchowości Kościoła prawosławnego, moralnie przekonać zbłąkane młode pokolenie, którego bełkot być może nawet kiedyś w przyszłości ktoś wspomni ze smutkiem ${ }^{20}$. W tej kwestii wspierał go Michaił Pogodin. W jednej ze swoich ostatnich książek, Proste stowa o mądrych rzeczach (Простал речь о мудреньıх вещах), która doczekała się trzech wydań w ciągu trzech lat, Pogodin, mówiąc o nihilizmie i nihilistach, doszedł do wniosku, że niedouczonych studentów, rozgniewanych seminarzystów, samouków-dyletantów, czyli ignorantów, którzy zapomnieli o Bogu i zamierzaja budować nowe spoteczeństwo [...] na krwi i plugastwie, nie należy karać, lecz przekonywać i uczyćc ${ }^{21}$. W tym kontekście Pogodin miał absolutną rację. Jego krytyczny wniosek o ignorancji radykalnej inteligencji został dowiedziony historycznie i socjologicznie i wielokrotnie był wsparty przez myślicieli rosyjskich.

Katkow, Tiutczew, Pogodin, Aksakow i wielu innych im współczesnych nie bez powodu łączyło rosyjskich radykalnych nihilistów i polskich powstańców. W opinii niemal wszystkich rosyjskich konserwatystów „wywrotowo-katolicka Polska” była fanatycznym zwolennikiem Zachodu i wiecznym zdrajcą "wobec swoich braci” - Słowian $^{22}$. Podkreślając stopień wpływu Polaków na opozycję w stosunku do rosyjskiego

17 Тепże, Письма к московским публицистам... 72. А. Ф. Аксаковой. Петербург. 4 января 1872, [w:] Федор Иванович..., s. 374.

18 Тепże, Письма к московским публицистам... 27. И. С. Аксакову. [Петербург.] 23 октября 1861, [w:] Федор Иванович..., s. 263.

19 Тепże, Письма к московским публииистам... 72. А.Ф. Аксаковой. Петербург, 4 января 1872, [w:] Федор Иванович..., s. 374.

20 Тепże, Письма к московским публицистам... 74. А.Ф. Аксаковой. Петербург. Пятница, 28 сентльря 1872, [w:] Федор Иванович..., s. 378.

21 М. Погодин, Простал речь о мудреньцх вещах, Москва 1873, s. 19, 135 i nast.

22 Por. Ф. Тютчев, Россия и Запад..., s. 143. 
samodzierżawia, Tiutczew zaznaczał: przestając czuć się Rosjanami, stają się nie kosmopolitami, lecz niezmiennie - Polakami23. Jeśli nihiliści, jak sądził Tiutczew, nie są zbyt poważnymi wrogami, to polscy księża, polska szlachta, polska emigracja, ale nie lud pol$s k i$, a właśnie oni są wrogami szczególnymi, niebezpiecznymi, świadomymi i dążącymi do celu ${ }^{24}$. Rosyjski historyk i etnograf, Niemiec z pochodzenia, urodzony w Warszawie, Aleksandr Fiodorowicz Hilferding wprost wskazywał na fakt, że polska szlachta to organizm, który ulegt rozktadowi, nie jest już zdolny do dalszego rozwoju ${ }^{25}$. Z kolei M. Pogodin wierzył, że obecna szlachta, jak starożytni Żydzi wyprowadzeni z Egiptu musi umrzeć w ciagu czterdziestu lat wędrówek po pustyni europejskiej, a nowa Polska z wyzwolonymi chtopami i miastami powinna rozpoczą́ nowe życie, nowa historię, w jedności $z$ Rosją ${ }^{26}$. Tak więc w rosyjskiej myśli politycznej wyraźnie zostały rozróżnione interesy ludu polskiego i polskiej szlachty. Wydarzenia okresu wyzwolenia chłopów i reform lat 60. w Rosji i Polsce ${ }^{27}$, kiedy liberalne działania rządu rosyjskiego były uporczywie „niezauważane” przez polską szlachtę i polską emigrację, które nadal protestowaty, defraudowaty środki publiczne, rozpowszechniaty fatszywe banknoty, podpalaty i domagaty się nie tylko granic z 1772 r., ale nawet Kijowa!, przekonały ich, że szlachta polska jest zupełnie obca nie tylko Słowianom, lecz także ludowi polskiemu. Szlachta ta, po pierwsze, jest pochodzenia zachodniego - celtyckiego lub romańskiego - po drugie, przybysze w Polsce nigdy nie taczyli się z tubylcami, jak potaczyli się u nas i w innych krajach. Dlatego, jak wnioskuje Pogodin: szlachta i lud tworza tam [w Polsce A. S., A. M.] do dnia dzisiejszego dwa zupetnie oddzielne spoteczeństwa ${ }^{28}$. Nie bez powodu wydawało się Pogodinowi i innym rosyjskim konserwatystom, że w opozycji do szlachty kosmopolitycznej, klerykalnej, nierozerwalnie związanej z przestarzałymi tradycjami anarchii feudalnej i egoizmu klasowego, całkowicie skierowanej ku przeszłości - stało chłopstwo - samoistne, nieświadomie przechowujące rodzime pierwiastki słowiańskie.

W świetle realiów historycznych takie stanowisko myślicieli rosyjskich nie stanowi zaskoczenia. W tym czasie konflikty między Polską a Rosją miały już długą tradycję. Sprawa polska była zapewne najbardziej drażliwą kwestią w polityce wewnętrznej Rosji przez większą część XIX w. Sprawa, będąca w centrum uwagi różnych sił politycz-

23 Tenże, Письма кмосковским публицистам... 11. А. Ф. Аксаковой. Петербург. 20 декабря 1866, [w:] Федор Иванович..., s. 279.

24 Por. tenże, Россия и Запад..., s. 143; tenże, Письма кмосковским публицистам... 11. А. Ф. Аксаковой. Петербург. 20 декабря 1866, [w:] Федор Иванович..., s. 279.

25 Рог.: А. Гильфердинг, Положение и задача России в Царстве Польском, „Русский инвалид” 1863, 16 XI, 17 XI.

26 М. Погодин, Польский вопрос, [w:] tenże, Статьи политические и польский вопрос (1856-1867), Москва 1876, s. 330.

27 Jak zaznacza Pogodin: polscy chtopi stali się takimi samymi wtaścicielami, jak i rosyjscy; miasta zostaty uwolnione z feudalnego jarzma, a liczba klasztorów - azylu lenistwa (i intryg politycznych) ograniczona. Wreszcie, niedawno ogtoszono szeroka amnestię: tysiące rodzin zestanych za udziat w buncie wrócity do ojczyzny, śledztwa zostaty przerwane, wstrzymane konfiskaty. Tamże, s. 329. 
nych, zarówno w Rosji, jak i w Europie, ostatecznie uwarunkowała rozbiory Polski w latach 1772, 1793 i 1795, w różny sposób inicjujące długi łańcuch tragicznych wydarzeń, wśród których można wymienić polskie powstania z lat 1830-1831 i 1863-1864 oraz następujące po nich nieudane próby inkorporowania Polski do Imperium Rosyjskiego czynione przez administrację carską. Wielu badaczy słusznie kojarzy „upadek Polski” z głębokim i długotrwałym kryzysem wewnętrznym, rozkładem polskiego ustroju państwowego, wszechwładzą i prywatą szlachty, które zostały wykorzystane przez sąsiadów, przede wszystkim Prusy i Austrię, a także Rosję, dla zwiększenia własnych terytoriów jej kosztem. Większość historyków za głównego architekta rozbiorów uważa pruskiego króla Fryderyka II, traktując udział Rosji jako wymuszony okolicznościami wojny rosyjsko-tureckiej z lat 1768-1774, dla której zakończenia niezbędna była neutralizacja otwartego sprzeciwu Austrii i skrytego - Prus ${ }^{29}$.

Ze szczególną siłą konflikt rosyjsko-polski zaostrzył się po powstaniu listopadowym w 1830 r., które stało się swoistą cezurą w relacjach między Petersburgiem i Warszawą. Do tego czasu podejmowano wiele prób, aby nakłonić do lojalności szlachtę z włączonej w skład Rosji części Polski. Wydaje się niemal paradoksem, że spośród wszystkich państw biorących udział w rozbiorze Polski, to właśnie w samodzierżawnej Rosji wysiłki owe na początku XIX w. były podejmowane ze szczególną intensywnością. Było to związane m.in. z polonofilskimi i liberalnymi sympatiami Aleksandra I, wykazywanymi przez cara przed 1812 r. „Polski nie ma, ale nadal żyjemy jak Polacy w Polsce” takie były uczucia mieszkańców Polski wschodniej. I nawet flirt Polski z Napoleonem nie miał prawie żadnego wpływu na charakter polityki rosyjskiej w Księstwie Warszawskim, którego przywództwo polityczne i wojskowe zostało zachowane w Królestwie Polskim, utworzonym na Kongresie Wiedeńskim. To nowe państwo nad Wisłą, mimo unii personalnej z carem rosyjskim, otrzymało jedną z najbardziej liberalnych konstytucji w Europie. W ostatnich latach panowania Aleksandra I konstytucja ta była coraz bardziej ograniczana. Po wstąpieniu na tron Mikołaja I kurs polityki Petersburga w stosunku do Polski zaostrzył się szczególnie. I mimo tego nowy imperator koronował się w maju 1829 r. w Warszawie, stając się królem Polski. Tym samym potwierdził konstytucję polską, przeciwko której zdecydowanie protestowali rosyjscy konserwatyści, słusznie zakładający, że jako monarchia konstytucyjna Królestwo Polskie stało w niemożliwej do przezwyciężenia sprzeczności z resztą Imperium Rosyjskiego (nie biorąc pod uwagę Wielkiego Księstwa Finlandii i Inflant). Dlatego gniew imperatora i konserwatystów rosyjskich z powodu „niewdzięczności zdrajców-Polaków” po powstaniu w $1830 \mathrm{r}$. był w pełni uzasadniony.

Dla „rosyjskiej” Polski zawsze charakterystyczne było przeciwstawienie państwa i społeczeństwa oraz dysonans między hierarchią wartości społecznych i publicznych.

29 Taki punkt widzenia przyjmuje np. M. Pogodin, autor koncepcji „narodowej”, zgodnie z którą Rosja, uczestnicząc w rozbiorach Polski, przywracała tylko do swego składu ziemie ukraińskie i białoruskie, nie przyłączyła ani piędzi z rdzennych terytoriów Polski. Podobnie jak wielu patriotów-rusofilów (przynajmniej w Rosji XIX w.) pośrednio i bezpośrednio stawiał Katarzynie II praktycznie jeden zarzut, mianowicie wzmocnienia Prus i przekazania Austrii ukraińskiej Galicji. Por. tenże, Пuсbмo к Гизо о польском вопросе, [w:] tenże, Статьи политические.., s. 399. 
Wraz ze stłumieniem polskiego buntu w latach 1830-1831, do którego przyłączyła się prawie cała elita władzy Królestwa Polskiego, zostały zniszczone resztki polskiej niepodległości. Polska powinna byta zginać - pisał Tiutczew i podkreślał dalej - nie samoistnoś́ jej ludowości polskiej - uchowaj Boże! Ale jej fatszywe uksztattowanie, to fatszywe poczucie narodowości, które zostato w nim zaszczepione $e^{30}$. W miejsce zniesionej Konstytucji z 1815 r. został ustanowiony Statut organiczny (1832), radykalnie ograniczający autonomię Królestwa, choć faktycznie nie wszedł on w życie. Sejm, Rada Państwa i wyższe instancje sądów zostały zlikwidowane, armia polska przestała istnieć. W miejsce autonomicznego okręgu szkolnego wprowadzono warszawski okręg szkolny, taki sam jak w Kijowie czy Kazaniu, na terytorium Królestwa wprowadzono powszechnie obowiązujący rosyjski system monetarny oraz system miar i wag. Władze zaczęły aktywnie ingerować w sprawy Kościoła katolickiego, rozpoczęła się kampania nawracania unitów na prawosławie ${ }^{31}$. Konflikt między państwem uosabianym przez Rosję i polskim społeczeństwem zaostrzył się. Ukształtował się nawet swego rodzaju społeczny kodeks honorowy, którego ograniczenia i reguły kształtowały życie w kraju o wiele bardziej niż prawo. Prestiż społeczny w oczach Polaków nie miał już nic wspólnego z prerogatywami państwowymi, gdyż uważano, że arystokraci polscy, którzy zajmowali wysokie stanowiska w administracji, nie służyli własnemu krajowi, a obcemu państwu.

Już w przededniu wydarzeń 1830 r. wrogość wobec Rosji zajmowała w świadomości większości polskiej szlachty miejsce szczególne. I tym radykalniej tendencja ta przejawiła się po klęsce. Nad Wisłą imperium carskie było postrzegane nie tyle jako przeciwnik polityczny, lecz raczej jako wcielenie zła, walkę narodu polskiego z Rosją postrzegano jako konflikt światła i ciemności. W taki więc sposób konflikt wychodził poza ramy polityczne i zyskiwał psedometafizyczny charakter, kiedy Rosji przypisywano dążenie nie tylko do despotycznego ujarzmienia swoich poddanych, ale także do zniewolenia całego „wolnego świata”, czyli Zachodu. Rewolucjoniści wszystkich krajów - wskazywał Tiutczew - pokładają swoje nadzieje w „możliwości krucjaty przeciwko Rosji”, gdzie „polem bitwy miałaby być Polska”32. Około 10 tys. polskich emigrantów przebywających na Zachodzie po $1831 \mathrm{r}$. kontynuowało tam swoje spory z Rosją i pojawiało się wszędzie tam, gdzie była prowadzona walka przeciwko Imperium carskiemu, stając się w oczach oficjalnych władz symbolem buntu i nieposłuszeństwa. Ale główne zwycięstwo udało im się osiągnąć na arenie europejskiej opinii publicznej, inicjując i pielęgnując to, co Tiutczew nazwał rusofobią. Za jedną z przyczyn gwałtownego pogorszenia wizerunku Rosji na Zachodzie po 1830 r. oraz faktu, że sympatię do Polski żywiło wielu Europejczyków, a do Rosji tylko nieliczni legitymiści, uznaje się wpływ polskiej emigracji.

Prawie trzy dekady po powstaniu listopadowym w stosunkach polsko-rosyjskich dało się zauważyć odprężenie. Po klęsce w wojnie krymskiej i wstąpieniu na tron Alek-

30 Ф. Тютчев, Россия и Запад..., s. 183.

31 Рог. В. Аьяков, Славянский вопрос в общественной жизни дореволюиионной России, Москва 1993.

32 Ф. Тютчев, Россия и Запад..., s. 141. 
sandra II w 1855 r. w Rosji nastąpiła, według słów Tiutczewa, „odwilż”, zaplanowano i zaczęto realizować wielkie reformy. W polityce reform sprawa polska nie została potraktowana marginalnie. Choć Aleksander II kategorycznie odmówił przywrócenia konstytucji z 1815 r., to zmiana klimatu nad Wisłą pod koniec lat 50. XIX w. była odczuwana przez wszystkich. Została ogłoszona amnestia dla więźniów politycznych, w której wyniku wróciło z Syberii wielu zesłańców. Jednocześnie jednak polscy generałowie i politycy unikali jakichkolwiek kroków, które mogłyby być interpretowane jako kolaboracja z Rosjanami. Rusofobiczna opinia publiczna w Królestwie Polskim miała paraliżujący wpływ na wszelkie próby normalizacji stosunków między Petersburgiem i Warszawą. Radykałowie, w przeciwieństwie do większości rozsądnie myślących Polaków sprzeciwiających się powstaniu zbrojnemu, popychali kraj w kierunku konfrontacji militarnej. Ich przewaga polegała na tym, że w skrajnej formie wyrażali wartości uznawane przez wszystkich Polaków: gotowość do walki o niepodległość kraju była moralnym obowiązkiem, z którego nikt nie mógł się wycofać. Główny nacisk kładziono przy tym nie na zwycięstwo, a na wolę sprzeciwu. Taki idealizm, w którego sferę przesunął się narodowy instynkt samozachowawczy Polaków, budził zdumienie i podziw na Zachodzie i otwartą nieakceptację w Rosji, tym bardziej że postawę wielu określała teza: Każdy, kto twierdzi, że jesteśmy Stowianami, jest zdrajca, bo my jesteśmy po prostu Polakami ${ }^{33}$.

Rosyjska publicystyka lat 60. poświęcona sprawie polskiej wyraziła myśl, że Polska, wobec której rząd rosyjski prowadził „politykę ugodową” i utrzymywał wiele lokalnych prerogatyw, których pozbawiona była ludność centralnej Rosji, nie umiała wykorzystać monarszego zaufania i przychylności i na liberalną politykę rządu odpowiedziała „rewolucją moralną" i zbrojnym buntem ${ }^{34}$. Jednym z przykładów niezdolności i niechęci Polaków do korzystania z przychylności monarszej, w wielu opiniach, był „system Wielopolskiego" - sposób zarządzania w Polsce od czerwca 1861 r. do października 1863 r., który doprowadził do powstania 1863-186435. Dokładnie analizując wydarzenia, wielu rosyjskich publicystów próbowało wnieść swój wkład, zarówno w Rosji, jak i za granicą, w kształtowanie opinii publicznej w zgodzie z istotą sprawy, a także odwoływać się do rozumu i sumienia polskich powstańców. W czasie trwania buntu ton wypowiedzi prasy rosyjskiej w kwestii polskiej był niezwykle ostry. Jednocześnie nikt nie zamierzał obwiniać o zbrodnie ${ }^{36}$ całego narodu polskiego. Te zbrodnie przeciw Rosjanom wyka-

33 Суt. zа: В. Аьяков, Славянский вопрос в общественной жизни..., s. 57.

34 „Rewolucja moralna” to w rzeczywistości kampania obywatelskiego nieposłuszeństwa, którego częścią były zebrania wiernych w kościołach, gdzie pod pozorem nabożeństw śpiewano pieśni patriotyczne i obchodzono rocznice upamiętnione w historii Rzeczpospolitej oraz msze żałobne i procesje, noszenie przez kobiety żałoby dla upamiętnienia ofiar walk o niepodległość Polski. Por. 3anadнııe окраинь Российской империи, red. М. Аолбилов, А. Милмер, Москва 2007, s. 148, Historia Rossica.

35 Istnieje obfita literatura dotycząca tego powstania. Ogromy korpus źródeł został opublikowany w serii: Восстание 1863 г. Аокументы и материальь, t. 1-25, Москва 1960-1986.

36 W nocy z 10 na 11 stycznia 1863 r. doszło do „nocnego mordu żołnierzy rosyjskich” przez grupy uzbrojonych powstańców, którzy zaatakowali 17 garnizonów rosyjskich; 31 marca, w pierwszy dzień prawosławnej Wielkanocy, został ogłoszony manifest o amnestii dla wszystkich uczestników powstania w Królestwie Polskim i w Kraju Zachodnim Imperium, którzy nie byli zamieszani w żadne 
zywał np. M. Pogodin, nazywając je sprawa partii zagranicznych rewolucjonistów, którzy, oprócz celów narodowych, realizuja wiele innych ${ }^{37}$. Takie stanowisko prasy w pełni odzwierciedlało nastroje, jakie panowały w społeczeństwie rosyjskim. Typowy przykład to epizod, który miał miejsce na Kongresie Słowiańskim w 1867 r., kiedy na bankiecie w Sokolnikach wystąpił czeski delegat Franciszek Władysław Rieger. Przed Kongresem odbył podróż do Paryża, gdzie prowadził rozmowy z polskimi środowiskami emigracyjnymi, a na Kongresie próbował przekonać rosyjskich uczestników o konieczności polityki kompromisu w kwestii polskiej. Rieger zgodził się m.in. z tym, że Polacy nie mają racji, odtaczając od narodu rosyjskiego jego gatąź matoruska (chodziło o Galicję), ale zachęcił Rosjan, aby oni również przyznali się, że nie mają racji, kiedy nie uznają prawa Polaków do „samodzielności narodowej”, mimo że ta gałą́ zachodniej Słowiańszczyzny różni się od Rosjan zarówno pod względem języka, jak i historii. Udowodnijcie, że nie chcieliście ich wynarodowić - zwrócił się Rieger do publiczności i wyraził nadzieję, że nasi rosyjscy bracia pierwsi wypowiedza piękne stowo chrześcijanskiej mitości i pojedna$n i a^{38}$. W odpowiedzi na to oświadczenie wystąpił książę Władimir Czerkasskij, który powiedział m.in., że Polska sama jest winna w temu, że straciła wolności przyznane jej przez Aleksandra I. Przytoczył wiele danych statystycznych, świadczących o tym, że Rosja dbała o rozwój oświaty w Polsce bardziej niż w rosyjskich guberniach, że podatki w guberniach nad Wisłą wynosiły tylko 4 ruble od mieszkańca, a w Rosji - 6 rubli, że chłopi w czasie reformy uwłaszczeniowej w Polsce otrzymali ziemię na korzystniejszych warunkach niż w Rosji. Dlatego, podkreślił Czerkasskij, jeśli Polacy uświadomią sobie to wszystko i przyjdą do nas z pokorą i skruchą, to będą dla nich szeroko otwarte nasze braterskie objęcia. W sprawozdaniu z Kongresu, po zrelacjonowaniu tych słów, odnotowano: Nie można opisać tego wrażenia, jakie wywarta mowa wielce szanownego oratora. Ttumy rzucity się, aby go objąć; ze wszystkich stron krzyczano: dziękujemy, jesteśmy wdzięczni, jesteśmy wdzięczni39.

Swego czasu, w połowie lat 60. Pogodin zauważył, że cała prasa europejska roi sie od artykułów na temat sprawy polskiej, że europejska waga w tej kwestii jest wykrzywiona i niedoktadna, jak zresztą we wszystkich innych wypadkach, gdy chodzi o rzeczy, które przynoszą korzyść lub czynią szkodę Rosji, która wiąż jawi się w ich wyobraźni jako jakieś przerażające widmo ${ }^{40}$. Podkreślał konieczność ostrej odpowiedzi dla europejskich rusofobów, formułowania i propagowania stanowiska „rosyjskiego”, „opinii rosyjskiej”, „rosyjskich” dowodów, potwierdzających „rosyjską” decyzję o rozwiązaniu sprawy polskiej. Jest to tym bardziej konieczne, jak wskazywał, że u podstaw rusofobicznych wystąpień prasy zachodniej leżą absurdy, podobne do twierdzeń niektórych

inne przestępstwa, pod warunkiem że złożą broń przed 1 maja. Ten kolejny gest miłosierdzia carskiego nie został przez powstańców przyjęty. Wynikiem powstania z 1863 r. była klęska Polaków i 30 tys. zabitych, straty rosyjskie obliczano na 3343 osób (w tym 2169 rannych).

Por. Банкет в Сокольниках, [w:] Всероссийская этнографическал выставка и славлнский съезд в Москве в мае 1867 года, Москва 1867, s. 347-348. 
„ekstremistycznie nastawionych Polaków”, że Rosja nie istnieje, że Rosji nie ma, nie ma Rusi, że jezyk rosyjski nie jest jezykiem stowiańskim! ${ }^{11}$. Jak się zdaje, wołał Pogodin, nie ma takich absurdów, które nie znalaztyby zwolenników, zwtaszcza jeśli stuża one oskarżeniu Rosji, która ciagle stanowi bielmo na oczach Europy - szkoda, że nie pypećna jezyku ${ }^{42}$.

Jednym z takich oskarżycieli Rosji był polski powstaniec, „paryski profesor historii” Franciszek Henryk Duchiński (1816-1893). W szeregu swoich prac, z których najważniejszą były Zasady dziejów Polski i innych krajów stowiańskich i Moskwy opublikowane w trzech częściach w Paryżu w latach 1858-1861, zupetnie poważnie [...] $z$ punktu widzenia lingwistycznego, historycznego, etnograficznego itd. ${ }^{43}$ bronił dogmatu, że Wielkorusi nie są Słowianami. Karol Marks w liście do Fryderyka Engelsa z dużym zainteresowaniem odniósł się do koncepcji Duchińskiego i wypowiadał swoje poparcie dla jego tez: twierdzi on, że wtaściwi Moskwicini, tzn. mieszkańcy dawnego Grand Duchy of Moscow, sa po większej częśi Mongotami albo Finami itd., tak samo jak mieszkańcy czesści Rosji potożonych dalej na wschód i jej dzielnic potudniowo-wschodnich [...]. Chciatbym, żeby Duchinski miat racje i żeby at all events poglad ten stat się dominujacy wśród Stowian ${ }^{44}$.

W istocie, pozbawione podstaw naukowych tezy Duchińskiego koncentrowały się na konieczności stworzenia swoistego bufora pomiędzy „aryjską” Europą a „turańską” Moskwą ${ }^{45}$; jest oczywiste, że rola ta przeznaczona była dla niepodległej Polski, obejmującej Ukrainę-Ruś, Białoruś, Litwę, Inflanty, Smoleńsk i Nowogród.

Idee Duchińskiego zostały entuzjastycznie przyjęte przez emigrację polską, marzącą o przywróceniu „Wielkiej Polski od morza do morza”, z zachwytem przyjęli je naznaczeni rusofobią francuscy intelektualiści i politycy: Henri Reagnault, Henri Martin, Théodore-Casimir Delamarre i in. Sam Duchiński w zadufaniu oświadczył, że jego poglądy nigdy zniszczonymi nie będa, jak nigdy ziemia Polski nie przestanie należeć do sys-

41 Tamże, s. 368. Konkretny przypadek takiego rusofobicznego niezrozumienia Pogodin zanalizował krytycznie w Odpowiedzi francuskiemu dziennikarzowi (6 VI 1863). Por. М. Погодин, Отповедь франиузскому журналисту [w:] tenże, Статьи политические и польский..., s. 413.

42 Tenże, Польский вопрос..., s. 368.

43 Маркс - Энгельсу, 24 июня 1865, [w:] К. Маркс и Ф. Энгельс. Сочинения, red. А. Рязонов, В. Адоратский, t. 31, Москва 1963, s. 106-107. [Cytat na podstawie wyd. pol.: K. Marks do F. Engelsa, Londyn, 24 VI 1865, [w:] K. Marks, F. Engels, Dzieta, t. 31: (Listy: styczeń 1864 - grudzień 1867), przeł. J. Nowacki, Warszawa 1975, s. 151 [przypis Redakcji].

44 Маркс - Энгельсу, 24 июня 1865, [w:] К. Маркс и Ф. Энгельс. Сочинения, red. А. Рязонов, В. ААоратский, t. 31, Москва 1963, s. 106-107. [Cytat na podstawie wyd. pol.: K. Marks do F. Engelsa, Londyn, 24 VI 1865..., s. 151-152 [przypis Redakcji].

45 Obaczymy - pisał Duchiński - że budowa fizyczna Ojczyzny naszej, przyczynia się, z swojej strony, do jedności jej mieszkańców z Narodami Zachodniej Europy; tak samo, jak pochodzenie mieszkańców Ojczyzny naszej, wyrabia, z swojej strony, też jedność: zobaczymy, że i sama fizyczna budowa Państwa Moskiewskiego oddziela mieszkańców onego od Europy, a taczy ich z mieszkańcami Azyi Środkowej do murów chińskich, tak jak ich tacza $i$ potrzeby umystowe i moralne, wyptywające z pochodzenia. F. H. Duchiński, Zasady dziejów Polski i innych krajów stowiańskich i Moskwy. Wyjaśnienie rzeczy co do pomnika majacego być postawionym w Nowogrodzie na pamiątkę zatożenia Państwa Moskiewskiego jakoby w 862 roku, cz. 2, Paryż 1859, s. 13. 
temu europejskiego, a ziemia Moskwy do systemu Azjatyckiego, chyba, że nazwiemy Azje Europa; a $i$ wówczas, będą dwie Europy, jak w rzeczy samej jest $i$ dzisiaj ${ }^{46}$. Jednak idyllę zniszczył Otto von Bismarck, który obalił napoleońskie II Cesarstwo, a wraz z nim - francuską rusofobię, po czym pisma Duchińskiego straciły poprzednią atrakcyjność, a wszyscy „nagle” zauważyli jawny dyletantyzm i tendencyjność polityczną autora.

Rosyjski rząd, po stłumieniu powstania w 1863 r., nie interesował się polskimi problemami narodowościowymi, wszelkie kompromisy i umowy z polskim społeczeństwem były dla niego wykluczone. W samej Polsce walka ze szlachtą i duchowieństwem katolickim była prowadzona nie tylko za pomocą środków siłowych, lecz także drogą reform, przeprowadzonych natychmiast po powstaniu w $1863 \mathrm{r}$. Jednak próby rusyfikacji Polski ani trochę nie ułatwiały jej inkorporacji do Imperium, dla coraz to nowych pokoleń patriotycznie myślących Polaków Rosja pozostawała głównym wrogiem, a w świadomości społecznej Rosjan ukształtował się negatywny obraz „Polaków”, którzy w oczach nierewolucyjnie nastawionego społeczeństwa zaczęli jawić się jako oprawcy rosyjskiego chłopstwa, judasze sprawy słowiańskiej, fanatycy religijni i egzaltowani nosiciele chimerycznych roszczeń imperialnych do dawno i bezpowrotnie umarłej „wielkiej Polski” i wreszcie jako zdeklarowani rusofobowie, inicjatorzy i inspiratorzy wszelkich ruchów i wystąpień naruszających narodowo-polityczną jedność Rosji.

Właśnie w tym czasie pod Wilnem - na „kresach” (wschodnich ziemiach dawnej Rzeczypospolitej) - w rodowym majątku swoich rodziców urodził się człowiek, któremu było sądzone odegrać szczególną rolę w historii Polski. Józef Klemens Piłsudski herbu Kościesza (1867-1935) nie był zainteresowany teoriami etnograficznymi, bardziej pociągały go idee społeczne i rewolucyjne, dlatego w 1884 r. „nazwał się” socjalistą i za główny cel życia postawił sobie fizyczne zniszczenie państwa rosyjskiego, a następnie odbudowanie na jego gruzach nowej Polski, dominującej w Europie Środkowej i Wschodniej.

Piłsudski - założyciel armii polskiej i przyszły dyktator odrodzonego państwa polskiego - był „jedynie” członkiem Centralnego Komitetu Robotniczego podziemnej Polskiej Partii Socjalistycznej (PPS) i redaktorem jej drukowanego organu „Robotnik”, w którym zamieścił swój artykuł Rosja (1895). W artykule tym przedstawił swoje negatywne poglądy na temat Rosji, których później nie zmienił. Istota ich była następująca. Rosyjski charakter narodowy i rosyjską historię, według Piłsudskiego, uformowała długa i ciężka niewola tatarsko-mongolska, która wszczepiła w ciągu kilka wieków w naród rosyjski ducha niewoli, pokory wobec władzy i godzenia się z $\operatorname{losem}^{47}$. Po omówieniu stanu wszystkich klas społeczeństwa rosyjskiego Piłsudski doszedł do wniosku, że [...] wszystkie klasy sa bardzo niewyraźnie rozgraniczone $i$, mają za soba niewolnicza przesztość, nie posiadaja tradycji walki politycznej $i$ zdolności do tączenia się, do organizowania się w partie polityczne. Jedyna zorganizowana sita w Rosji jest masa urzędnicza, ta armia caratu. Jedyna to teżjest świadoma sita ${ }^{48}$.

46 Tamże, s. 30

47 Por. J. Piłsudski, Wybór pism, wstęp W. Suleja, K. Polechoński, wybór i oprac. W. Suleja, Wrocław 1999, s. 8, Skarby Biblioteki Narodowej.

48

Tamże, s. 16. 
Piłsudski nie pokłada absolutnie żadnej nadziei w proletariacie rosyjskim, a siłą zdolną do zniszczenia samodzierżawia w jego rozumieniu staje się... ludność krajów podbitych przez carat: Polacy, Litwini, Łotysze, Rusini (tj. narody zajmujące terytoria należące w przeszłości do Rzeczypospolitej $)^{49}$. A więc wszystko wróciło do punktu wyjścia - nawet u nielubiącego etnografii rewolucjonisty Piłsudskiego wyższość cywilizacyjna Polaków (i narodów, które w przeszłości zetknęły się z Polakami) warunkuje ich wiodącą rolę w przyszłym zniszczeniu „barbarzyńskiej” Rosji...

Kończąc naszą historię, nie sposób nie zacytować Iwana Aksakowa, który sformułował „rosyjski pogląd” na Rosję. Prawdziwa Ruś - pisał - to żywe, integralne ciato, a nie mozaikowy zbiór różnowierców i różnoplemieńców. Do tego ciata moga przylgną́ inne osobowości i ciata narodowe i moga przeksztatcić się w jego organiczna istotę lub po prostu korzystać z jego ochrony - ale caty sens istnienia, cata sita, rozum, cata misja historyczna, caty historyczny raison d'être - zawiera się wtaśnie $w$ Świętej Rusi... ${ }^{50}$

I jeszcze: Ile anomalii zrodzita $w$ systemie politycznym nasza wieloletnia polityka antynarodowa! Ile jeszcze przyjdzie nam rozprawiać się z tym, co zostato nawyprawiane pod wptywem fatszywie pojętego europeizmu, humanizmu, liberalizmu - ze szkoda dla prawdziwych interesów rosyjskiej ludowości, rosyjskiej państwowości, honoru i potęi is . Sens i treść tej opinii Aksakowa jest nie tylko jasny, ale też bliski współczesnemu Rosjaninowi.

Tłumaczenie: Magdalena Romanowska

\section{BIBLIOGRAFIA}

Аксаков И., Отчего так нелегко живется в России?, Москва 2002.

Аксаков И., Полное собранине сочинений, t. 6: Прибалтийский вопрос. Внутренние дела России. Введение к украинским ярмаркам, Москва 1887.

Восстание 1863 г. Аокументыь и материальь, t. 1-25, Москва 1960-1986.

Всероссийскал этнографическал выставка и славянский съезд в Москве в мае 1867 года, Москва 1867.

49 Por. tamże, s. 18.

50 И. Аксаков, Где органическал сила России?, [w:] tenże, Отчего так нелегко живется в России?, Москва 2002, s. 260. Niestety, w Rosji stało się jednak to, co proroczo przewidział Samarin: Jeśliby kiedykolwiek spoteczeństwo rosyjskie odwrócito się plecami do Kraju Nadbattyckiego, machnęto ręka na Polskę, zapomniato o Kaukazie i Finlandii, oduczyto się w ogóle interesować swoimi peryferiami, to oznaczatoby to, że przestato traktować Rosje jako catość. Ten dzień bytby poczatkiem jej rozktadu. Tego dnia zatryumfowaliby przedstawiciele wszystkich wrogich partii i narodowości; Mirostawski i D. K. Schedo-Ferroti, Hercen i von Bock zapomnieliby na chwile o dzielacej ich różnicy zdań; zbiegliby się ze wszystkich krańców Europy na braterska ucztę i świętowaliby razem wigilie politycznego upadku Iтретіит. Ю. Самарин, Сочинения, t. 8: Окраины России, Москва 1890, s. XVII.

51 И. Аксаков, Еще об „Окраинах” Ю.Ф. Самарина, [w:] tenże, Полное собранине сочинений, t. 6: Прибалтийский вопрос. Внутренние дела России. Введение кукраинским ярмаркам, Москва 1887, s. 167. 
Гильфердинг А., Положение и задача России в Царстве Польском, „Русский инвалия” 1863, $16 \mathrm{XI} ; 17 \mathrm{XI}$.

Аьяков В., Славянский вопрос в общественнойжизни дореволюиионной России, Москва 1993. Западнье окраиньь Российской империи, red. М. Аомбилов, А. Мимлер, Москва 2007, Historia Rossica.

Ильин И., Мировая политика русских государей, [w:] tenże, Наши задачи. Статьи 1948-1954 г2., t. 1, Париж 1956.

К. Маркс и Ф. Энгельс. Сочинения, red. А. Рязонов, В. Адоратский, t. 31, Москва 1963.

Первый всеславянский съезд в России. Его причины и значение, Москва 1867.

Погодин М., Простал речь о мудреньхх вещах, Москва 1873.

Погодин М., Статьи политические и польский вопрос (1856-1867), Москва 1876.

Самарин Ю., Сочинения, t. 8: Окраины России, Москва 1890.

Тютчев Ф., Россия и Запад. Книга пророчеств. Статьи, стихи, Москва 1999.

Тютчев Ф., Сочинения в 2 томах, t. 2: Письма, Москва 1980.

Федор Иванович Тютчев, red. С. Макашин, К. Пигарев, Т. Аинесман, ks. 1, Москва 1988, Аитературное наследство, t. 97.

Duchiński F. H., Zasady dziejów Polski i innych krajów stowiańskich i Moskwy. Wyjaśnienie rzeczy co do pomnika mającego być postawionym w Nowogrodzie na pamiątkę zatożenia Państwa Moskiewskiego jakoby w 862 roku, cz. 2, Paryż 1859.

Heller M., Historia Imperium Rosyjskiego, przeł. E. Melech, T. Kaczmarek, Warszawa 2000.

K. Marks do F. Engelsa, Londyn, 24 VI 1865, [w:] K. Marks, F. Engels, Dzieta, t. 31 (Listy: styczeń 1864 - grudzień 1867), przeł. J. Nowacki, Warszawa 1975.

Piłsudski J., Wybór pism, wstęp W. Suleja, K. Polechoński, wybór i oprac. W. Suleja, Wrocław 1999, Skarby Biblioteki Narodowej.

Aleksandr Andriejewicz SZYRINIANC - doktor habilitowany nauk politycznych, profesor, kierownik Katedry Historii Nauk Społeczno-Politycznych Wydziału Politologii Moskiewskiego Uniwersytetu Państwowego im. M. Łomonosowa.

Anna Waleriewna MYRIKOWA - doktor nauk politycznych, docent w Katedrze Historii Nauk Społeczno-Politycznych Wydziału Politologii Moskiewskiego Uniwersytetu Państwowego im. M. Łomonosowa. 